\title{
Effects of Extraction Methods of Medicinal Plants on Human Growth of Neuroblastoma SK-N-SH Cells
}

\author{
Jung Min Kwon ${ }^{1,2}$, Yeon Gyu Moon ${ }^{1,2}$, Young Suk Kim², Ji Young Jung ${ }^{2,3}$, Yeong Lae Ha $a^{1,2}$ and Jae Kyung Yang ${ }^{2,3}$ \\ ${ }^{I}$ Division of Applied Life Sciences (BK21 programs), ${ }^{2}$ Institute of Agriculture \& Life Sciences, and ${ }^{3}$ Department of Environmental Forest \\ Products, Gyeongsang National University, Jinju 660-701, Korea
}

Received July 7, 2011 /Revised August 26, 2011 /Accepted August 26, 2011

\begin{abstract}
Extraction methods of medicinal plants were evaluated for growth enhancing effects of human neuroblastoma SK-N-SH cells. Hot-water extraction (reflux for $5 \mathrm{hr}$ ), hot-water extraction post treatment $\left(100^{\circ} \mathrm{C}\right.$ or $120^{\circ} \mathrm{C}, 90 \mathrm{~min}$ ) and ethanol extraction (reflux for $5 \mathrm{hr}$ ) methods were applied to Angelica gigas, Rhemania glutinosa, Paeonia lactiflora and Cnidium officinale samples to extract their constituents. Cells were treated for $2 \mathrm{hr}$ with various concentrations of extracts $(0,0.5,1,2,4 \mathrm{\mu g} / \mathrm{\mu l}$ media) prior to $\mathrm{H}_{2} \mathrm{O}_{2}(250 \mu \mathrm{M})$ treatment for $2 \mathrm{hr}$ to provide oxidative stress. Cell viability, caspase- 3 expression and apoptosis were measured for cells treated with sample extracts. Hot-water extract exhibited a stronger growth enhancing and apoptosis protecting ability than other extracts. These activities were shown at less than $1 \mu \mathrm{g} / \mu \mathrm{l}$ concentration, and not greater than $2 \mu \mathrm{g} / \mu \mathrm{l}$ concentration. Hot-water extract contained more polyphenolic compounds than other extracts coming along with stronger antioxidant activity. The efficacy of antioxidant activity was stronger in the hot-water extract of Angelica gigas than other hot-water extracts of medicinal plants. These results suggest that hot-water extraction is an appropriate method to extract materials for growth enhancing and apoptosis protection of SK-N-SH cells, and hot-water extracts of Angelica gigas might be useful materials for protection from aging brain cells.
\end{abstract}

Key words : Apoptosis, Angelica gigas, antioxidant, extraction methods, human neuroblastoma SK-N-SH cells, polyphenols

\section{서 론}

고도의 의료기술 발달로 평균 수명과 노인 인구가 증가함에 따라 치매 환자도 증가하여 치매 노인 관리가 심각한 사회문 제로 대두되고 있다. 우리나라의 치매 유병률은 유형 및 지역 에 따라 다르지만 1997년 기준 65세 이상 노인 인구 중 $8.3 \%$ 였 으며, 2010 년에는 $8.6 \%, 2020$ 년에는 $9 \%$ 로 증가 될 것으로 추정 되고 있다[17].

치매는 증상군으로 질환이 진행되면서 인지장애와 기능장 애가 심해짐에 따라 조기 진단과 치료가 중요하다. 혈관성 치 매는 초기에 진단하여 치료하면 병의 진행을 막을 수 있고, 퇴행성 질환인 알쯔하이머형 치매도 조기 발견하여 치료하고 있다. 현재 한약재로부터 기능성 물질 및 소재의 개발은 주로 항암, 항산화(항노화), 항동맥, 항관절염 등에 국한 되어 있으 며[31], 인지능력 향상에 이용되는 소재나 제재를 개발한 경우 는 많지 않다. 당귀, 건지황 등의 한약재가 인지능력 향상 및 예방에 효과적이라는 보고[12,16,30]가 있지만, 이들의 구체적 인 신경세포에 대한 작용 기작이나 추출 방법에 관한 연구는 없다.

*Corresponding author

Tel : +82-55-772-1862, Fax : +82-55-772-1869

E-mail : jkyang@gnu.ac.kr
한약재의 항암성이나 만성질병 예방 및 치료 연구를 위해 이들 한약재로부터 유효성분을 추출하는데, 이들의 추출을 위 하여 주로 유기용매나 고온 및 고압을 사용하며[5], 한약재가 함유하고 있는 성분과 함량은 추출 방법과 용매 종류에 따라 달라진다. 그러나 이들의 경우와는 달리 한약재의 인지능력 향상, 치료, 예방 등에 관한 효과 검증은 신경세포의 보호가 필요하기 때문에 추출 방법이 상기 방법과는 상이하여야 할 것으로 생각된다.

따라서 본 연구는 추출 방법에 따른 인체신경모세포 SK-N-SH에 대한 국내산 한약재 추출물의 보호효과에 대하여 연구하였다. 한약재는 당귀, 건지황, 작약, 천궁을 사용하였고, 성분의 추출은 열수추출법, 에탄올추출법, 증숙추출법 $\left(100^{\circ} \mathrm{C}\right.$ 및 $120^{\circ} \mathrm{C}, 90$ 분 후 열수추출)을 사용하였다.

\section{재료 및 방법}

\section{재료}

국내산 당귀, 천궁, 작약, 건지황은 경남생약농협 (Sancheong, Korea)에서 구입하였고, human neuroblastoma SK-N-SH 세포는 한국세포주은행(Korea Cell Line Bank, Seoul, Korea)에서 구입하여 사용하였다. Dulbecco's Modified Eagle Medium/Ham'F-12 nutrient mixture (DMEM/F-12), 
fetal bovine serum (FBS), penicillin $(10,000 \mathrm{U} / \mathrm{ml}) /$ streptomycin $(10,000 \mu \mathrm{g} / \mu \mathrm{l})$, phosphate buffer saline (PBS), $0.25 \%$ trypsin-EDTA는 Gibco-BRL (Carlsbad, CA)에서 구입하여 사용 하였으며 3-(4,5-dimethylthiazol-2yl)-2,5-diphenyltetrazolium (MTT)은 Amresco (Solon, OH)에서 구입하였다. Dimethyl sulfoxide (DMSO), propidium iodide (PI), RNase, Hoechst33258, $\beta$-actin, gallic-acid, 2,2-diphenyl-1- picrylhydrazyl (DPPH), Folin-Ciocalter's phenol 시약은 SigmaAldrich (St. Louis, MO)에서 구입하여 사용하였다. Cell culture dish는 Nunc (New York)에서 구입하였고, protein extraction buffer (Pro-Prep)은 iNtRON Biotechnology inc. (Seoul, Korea)에서 구입하였으며, enhanced chemiluminescence (ECL)용액은 Elpis-Biotech (Daejeon, Korea)에 서 구입하여 사용하였다. Caspase-3 antibody는 Cell Signaling Technology (Danvers, MA)에서 구입하였고, goat anti-rabbit, goat anti-mouse antibody는 Santa Cruz Biotechnology ( Santa Cruz, CA)에서 구입하였다. Gel transfer kit (iblot), transfer stack PVDF membrane은 Invitrogen (Carlsbad, CA)에서 구입하여 사용하였다. 그 외 사용된 시약 은 reagent grade 이상이었다.

\section{추출물 시료조제}

한약재 시료는 실온에서 음건하여 분쇄하였다. 에탄올추출 및 열수추출은 시료 $4 \mathrm{~g}$ 을 각각 에탄올 $(600 \mathrm{ml})$ 및 증류수 $(600$ $\mathrm{ml}$ )에 침지하여 5 시간 환류냉각하여 추출하였다. 증숙추출은 분쇄한 시료 $30 \mathrm{~g}$ 을 $100^{\circ} \mathrm{C}$ 및 $120^{\circ} \mathrm{C}$ 에서 90 분간 증숙처리 후 건조 $\left(45 \pm 3^{\circ} \mathrm{C}\right)$ 한 것을 환류냉각하여 5 시간 열수추출하였 다. 이들 추출물을 감압 농축한 다음 동결 건조하여 정량하고 시료로 사용하였다.

\section{세포배양 및 시료처리}

SK-N-SH 세포는 $10 \%$ FBS와 penicillin/streptomycin이 함 유된 DMEM/F-12 배지에서 5\% $\mathrm{CO}_{2}$ 가 공급되는 배양기(3 $7^{\circ} \mathrm{C}$ )로 배양하였다. 세포가 $80 \%$ 정도 자라면 $0.25 \%$ tryp$\sin$-EDTA 용액 $1 \mathrm{ml}$ 를 5 분간 처리하고 원심분리 $(1,500 \mathrm{rpm}$, 5 분)하여 pellet을 분리하였다. 이 pellet을 DMEM/F-12 배지 로 희석하여 실험에 사용하였다. 시료의 세포독성 분석은 24 well plate $\left(1.5 \times 10^{5}\right.$ cell $/ 0.5 \mathrm{ml} /$ well $)$, apoptotic sub-G1기 분 석 및 caspase- 3 분석은 $10 \mathrm{~cm}$ culture dish $\left(5 \times 10^{5} \mathrm{cell} / \mathrm{dish}\right)$, 핵의 형태학적 변화 분석은 $3 \mathrm{~cm}$ culture dish $\left(5 \times 10^{5}\right.$ cell/dish)에서 24시간 배양하였다. 이들로부터 배지를 제거하 고 PBS로 세척(3 회)후 serum free media (SFM)를 가하고 시 료를 농도별 $(0,0.5,1,2,4 \mathrm{\mu g} / \mathrm{\mu l} \mathrm{SFM})$ 로 2시간 처리하였다. 다시 배지를 제거한 후 $\mathrm{PBS}$ 로 세척(3 회)하고 $\mathrm{H}_{2} \mathrm{O}_{2} \quad 250 \mu \mathrm{M}$ 을 2시간 처리하였다.

\section{세포독성 측정}

세포 독성은 Rakib (34)의 방법에 준하여 MTT assay법을 사 용하였다. 시료 및 $\mathrm{H}_{2} \mathrm{O}_{2}$ 가 처리된 세포의 배지를 제거하고 $\mathrm{PBS}$ 로 세척 후 MTT 시약을 $5 \mathrm{mg} / \mathrm{ml}$ 의 농도가 되게 $\mathrm{PBS}$ 에 녹여 이를 $100 \mu \mathrm{l} /$ well씩 분주하고 은박지를 씨워 3 시간 동안 $37^{\circ} \mathrm{C}$ incubater에서 반응시켰다. MTT 시약을 제거하고 PBS로 세척 후 DMSO를 $200 \mu \mathrm{l} /$ well씩 분주하여 생성된 formazan crystal 을 녹인 후 96 well plate에 100 l/well씩 옮겨서 Anthos2020 model Microplate Reader (Anthos Labtech Instruments, Wals., Austria)로 $570 \mathrm{~nm}$ 에서 흡광도를 측정하였다.

\section{Apoptotic sub-G1기 분석}

Apoptotic sub-G1기 분석은 Kim [15]의 방법에 준하여 분 석하였다. 시료 및 $\mathrm{H}_{2} \mathrm{O}_{2}$ 가 처리된 세포의 배지를 제거하고 $\mathrm{PBS}$ 로 세척(3 회)후 $70 \%$ 에탄올 $1 \mathrm{ml}$ 을 처리하여 $-20^{\circ} \mathrm{C}$ 에서 24 시간 고정하였다. 다시 $\mathrm{PBS} 1 \mathrm{ml}$ 로 세척(3 회)하고 1 $\mathrm{mg} / \mathrm{ml}$ 의 RNase와 $50 \mu \mathrm{g} / \mathrm{ml}$ 의 PI가 함유되어있는 PBS를 500 $\mu \mathrm{l}$ 씩 처리한 다음 $37^{\circ} \mathrm{C}$ 에서 20 분간 반응시켰다. 이를 Facs용 tube로 옮겨 Facs Caliular flow cytometer (BD Bioscience, San Jose, CA)를 이용하여 10,000 개의 세포 DNA 함량을 분석 하였다. 데이터는 CellQuestPro software (BD Biosciences)를 이용하여 분석하였다.

\section{핵의 형태학적 변화 분석}

Hoechst33258 염색은 Islam [9]의 방법에 준하여 실시하였 다. 시료 및 $\mathrm{H}_{2} \mathrm{O}_{2}$ 가 처리된 세포의 배지를 제거하고 $\mathrm{PBS}$ 로 세척 (3 회)후 $4 \%$ paraformaldehyde로 $4^{\circ} \mathrm{C}$ 에서 30 분 동안 고정하였 다. 고정한 세포를 $\mathrm{PBS}$ 로 3 회 세척한 후 $1 \mathrm{mg} / \mathrm{ml}$ Hoechst33258이 함유된 PBS를 5 씨처리하여 상온에서 30 분간 염색하였다. 그리고 Fluorescence microscope (Olympus DP70 Digital Camera System)을 이용하여 핵 염색을 관찰하였다.

\section{Caspase-3 발현 분석}

Western blot 분석은 Kim [15]의 방법에 준하여 실시하였 다. 시료 및 $\mathrm{H}_{2} \mathrm{O}_{2}$ 가 처리된 세포의 배지를 제거하고 $\mathrm{PBS}$ 로 세척(3 회) 후 처리구별로 모아서 lysis buffer를 700 lㅣ씩 처리 하여 세포 파쇄기로 1 분간 파쇄하고 원심분리 $(3,000 \mathrm{rpm}, 5$ 분) 후 상등액만을 따로 모았다. Acrylamide $10 \%$ gel을 이용하 여 전기영동 후 western blot transfer kit를 이용하여 transfer 하였다. 그 membrane을 5\% BSA에 24시간 blocking 시키고 $1 \mathrm{XTTBS}$ 로 세척(15 분, 3 회)하였다. 다시 $5 \% \mathrm{BSA}$ 에 각각의 caspase-3, $\beta$-actin을 5\% BSA에 1:1000, 1:2000으로 희석시켜 반응시킨 후 $1 \mathrm{X}$ TTBS로 세척(15 분, 3 회)하고 $5 \% \mathrm{BSA}$ 에 각각 의 2차 항체(goat-anti rabbit, goat-anti mouse)를 적정 비율로 희석시켜 반응시키고 $1 \mathrm{XTTBS}$ 로 세척(15 분, 3 회)하였다. 각 membrane을 $3 \mathrm{M}$ paper로 수분을 제거하고 양 면을 ECL용액 에 1 분씩 반응시킨 후 감광 kit를 이용하여 감광하였다. 


\section{항산화능 측정}

항산화능은 Blois의 방법[2]에 준하여 실시하였다. 시료 추 출물을 $0.5 \mathrm{mg} / \mathrm{ml}$ 과 $0.25 \mathrm{mg} / \mathrm{ml}$ 농도로 제조한 후 $0.3 \mathrm{mM}$ $\mathrm{DPPH} / \mathrm{methanol}$ 용액 $1 \mathrm{ml}$ 에 시료 $0.6 \mathrm{ml}$ 를 첨가하여 Spectrophotometer (X-ma 3000pc, Human corporation, Seoul, Korea)를 이용하여 $517 \mathrm{~nm}$ 에서 흡광도를 측정하였다.

\section{총 페놀 함량 분석}

총 페놀 함량 측정에는 Folin-Deins법[6]을 사용하였다. 시 료 추출물 $5 \mathrm{mg}$ 을 증류수 $10 \mathrm{ml}$ 에 녹여 여과하여 사용하였다. 시료 $200 \mu 1$ 를 증류수 $2.6 \mathrm{ml}$ 과 Folin-Ciocalter's phenol 시약 $200 \mu 1$ 를 첨가하여 6 분간 상온에서 반응시켰다. $7 \%(\mathrm{w} / \mathrm{v})$ $\mathrm{Na}_{2} \mathrm{CO}_{3}$ 용액 $2 \mathrm{ml}$ 을 첨가하고 90 분간 정치한 후 $750 \mathrm{~nm}$ 에서 흡광도를 측정하였다. 표준물질은 gallic acid $(20,60,80,100$, $500 \mathrm{ppm})$ 를 사용하였다.

\section{결 과}

SK-N-SH cell의 oxidative stress 대한 한약재 열수추 출물의 효과

Oxidative stress에 있는 SK-N-SH 세포의 증식에 대한 한약 재 추출물의 효과를 검토하기 위하여 당귀, 천궁, 작약, 건지황

A

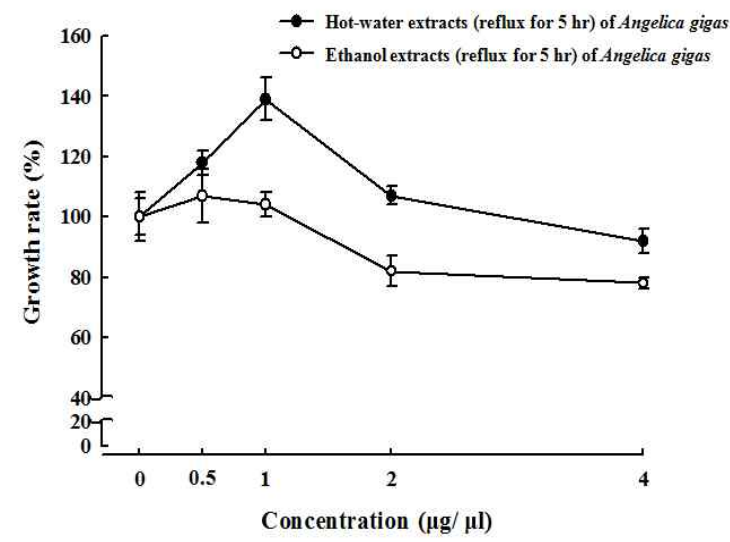

C

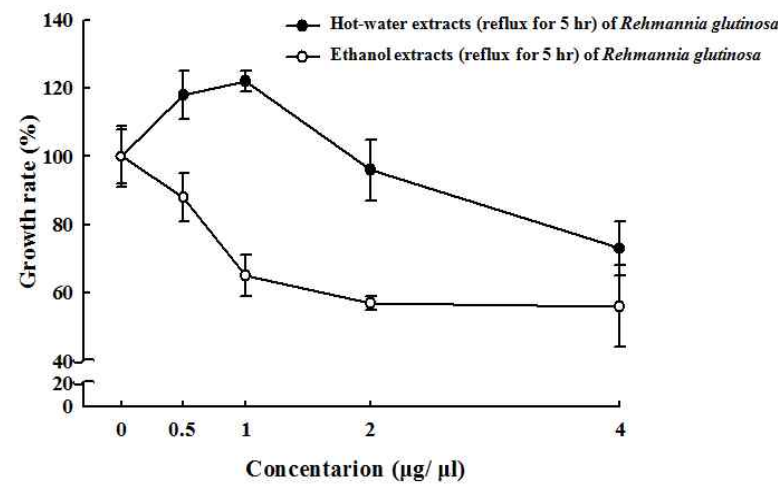

열수 및 에탄올추출물을 $0,0.5,1,2,4 \mu \mathrm{g} / \mu \mathrm{l}$ 농도로 2시간 처리하였다. 다음 $\mathrm{H}_{2} \mathrm{O}_{2}$ 를 2 시간 처리 후에 MTT assay로 세포 의 생육정도를 측정하였다. Fig. $1 \mathrm{~A}$ 에서는 당귀 열수추출물과 당귀 에탄올추출물의 oxidative stress에 대한 효과를 나타내 고 있다. 당귀 열수추출물은 $1 \mu \mathrm{g} / \mu \mathrm{l}$ 농도까지 SK-N-SH 세포 증식을 $139 \%$ 까지 증가시켰고, $2 \mu \mathrm{g} / \mu \mathrm{l}$ 이상의 농도에서는 강 한 독성을 나타내었다. 반면에 당귀 에탄올추출물은 열수추출 물보다는 효과가 낮았고, $2 \mu \mathrm{g} / \mu \mathrm{l}$ 농도 이상에서는 독성이 나 타났다. 따라서 당귀 열수추출물 $1 \mu \mathrm{g} / \mu \mathrm{l}$ 의 농도에서 가장 우 수한 증식 효과를 나타내었다.

Fig. $1 \mathrm{~B}$ 에서는 작약 열수추출물과 에탄올추출물의 oxidative stress에 대한 효과를 나타내고 있다. 작약 열수추출물은 $1 \mu \mathrm{g} / \mu \mathrm{l}$ 농도까지 SK-N-SH 세포의 oxidative stress에 대한 효과를 $120 \%$ 까지 증가시켰고, 그 이상의 농도에서는 독성을 나타내었다. 반면에 에탄올추출물은 모든 농도에서 독성을 나 타내었다. 따라서 작약은 열수추출물 $1 \mathrm{\mu g} / \mathrm{ul}$ 의 농도가 가장 우수한 효과를 나타내었다.

Fig. $1 C$ 에서는 건지황 열수추출물과 건지황 에탄올추출물 의 oxidative stress에 대한 효과를 나타내고 있다. 건지황 열수 추출물은 $1 \mathrm{\mu g} / \mu \mathrm{l}$ 농도까지 SK-N-SH 세포의 생존율을 $122 \%$ 까지 증가시켰고, $2 \mu \mathrm{g} / \mu \mathrm{l}$ 이상의 농도에서는 이 세포에 대한 강한 독성을 나타내었다. 반면에 에탄올추출물은 모든 농도에

B
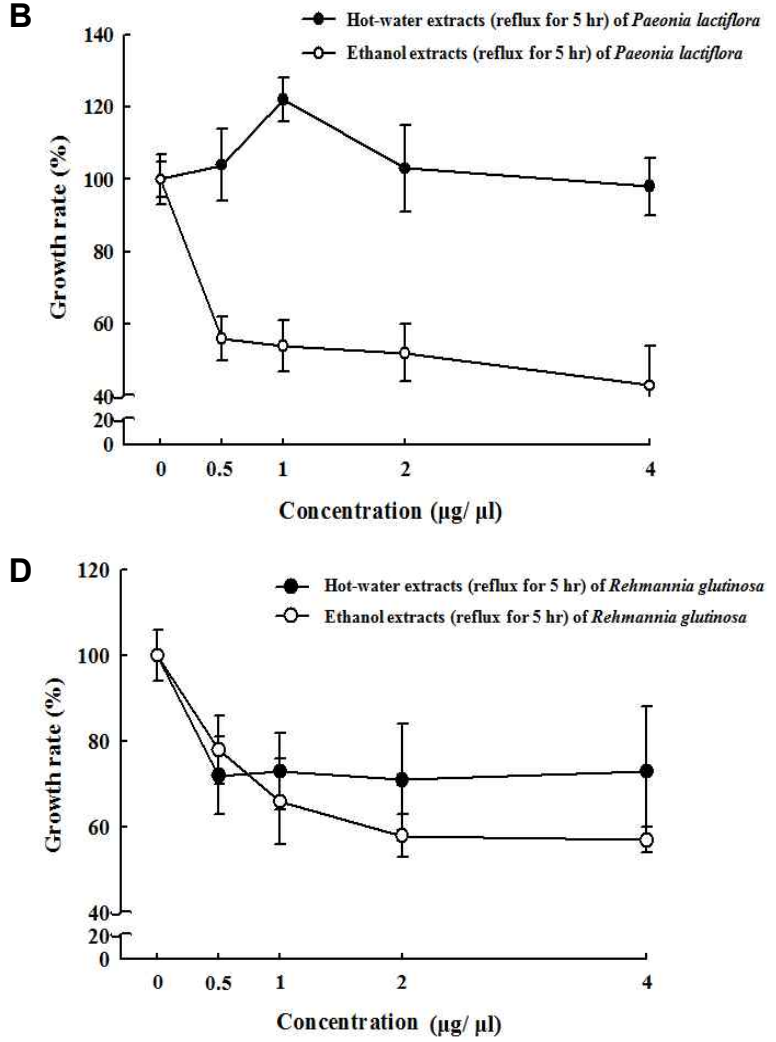

Fig. 1. Effects of hot-water and ethanol extracts of medicinal plants on the proliferation of SK-N-SH cells. Cells were exposured to sample $2 \mathrm{hr}$ prior to $\mathrm{H}_{2} \mathrm{O}_{2}$ treatment. $2 \mathrm{hr}$ later after $\mathrm{H}_{2} \mathrm{O}_{2}$ treatment, cell proliferation was measured by MTT assay. 
Table 1. Hot-water extracts of Angelica gigas, Cnidium officinale, Paeonia lactiflora and Rehmannia glutinosa

\begin{tabular}{lc}
\hline Samples & Content $(\%)^{1)}$ \\
\hline Angelica gigas (Dang-gui) & $32.4 \pm 3.1 \mathrm{~d}^{2)}$ \\
Cnidium officinale (Chun-goong) & $38.6 \pm 1.9 \mathrm{c}$ \\
Paeonia lactiflora (Jak-yak) & $45.4 \pm 1.0 \mathrm{~b}$ \\
Rehmannia glutinosa (Gun-ji-hwang) & $73.5 \pm 0.4 \mathrm{a}$ \\
\hline
\end{tabular}

${ }^{1)}$ Based on the dry weight

${ }^{2)}$ Mean followed by the same letter within the same column are not significantly different $(p<0.05)$ by Duncan's new multiple range test $(n=3)$

서 독성을 나타내었다. 따라서 건지황의 경우 열수추출물 1 $\mu \mathrm{g} / \mu \mathrm{l}$ 의 농도에서 우수한 세포 증식 효과를 나타내었다.

Fig. $1 \mathrm{D}$ 에서는 천궁은 당귀나 건지황 및 작약과 달리, 열수 추출물과 에탄올추출물의 모든 농도에서 SK-N-SH 세포에 대 한 oxidative stress 보호 효과를 나타내지 않았다.

따라서 당귀, 건지황 및 작약의 열수추출물이 $\mathrm{H}_{2} \mathrm{O}_{2}$ 로 유발 한 oxidative stress로부터 SK-N-SH 세포를 강력하게 보호하 였고, 그 중 당귀가 가장 우수한 효과를 나타내었다. 열수추출 물의 함량은 당귀가 $32.4 \%$ 로 가장 낮았고, 건지황이 $73.5 \%$ 로 가장 높았다(Table 1).

\section{A}

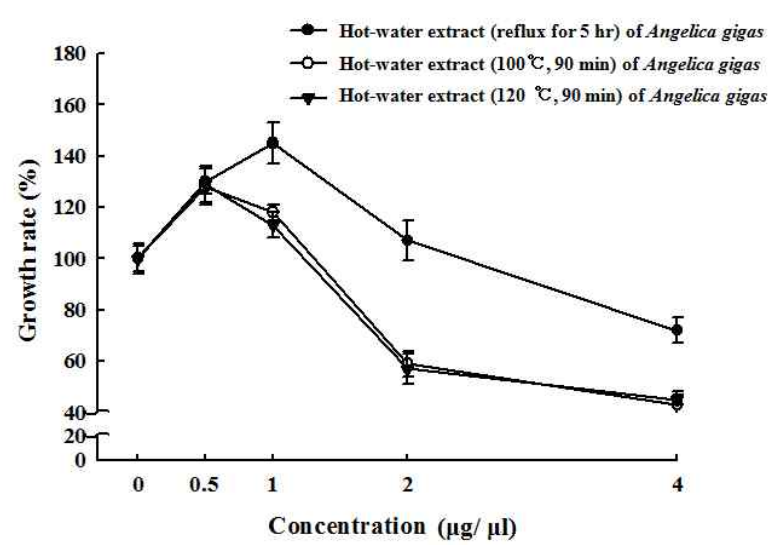

$\mathrm{SK}-\mathrm{N}-\mathrm{SH}$ cell의 oxidative stress에 대한 증숙처리 추 출물의 효과

한약재의 열수추출물이 oxidative stress억제 효과가 우수 하였기 때문에, 한약재 증숙추출물의 효과를 조사하였다. Fig. $2 \mathrm{~A}$ 에서는 당귀의 열수추출물과 증숙추출물의 SK-N-SH 세포 에 대한 oxidative stress 억제효과를 나타내고 있다. 당귀 열수 추출물을 $0,0.5,1,2,4 \mathrm{\mu g} / \mathrm{\mu l}$ 농도로 처리한 결과 각각 100 , $131,150,101,63 \%$ 의 세포 성장률을 나타내어 $2 \mu \mathrm{g} / \mu \mathrm{l}$ 의 농도 에서부터 세포성장률이 감소하였다. $100^{\circ} \mathrm{C}$ 에서 90 분간 증숙 추출물 효과는 $0,0.5,1,2,4 \mathrm{\mu g} / \mathrm{\mu l}$ 처리 농도에서 100,123 , $106,54,40 \%$ 였고, $120^{\circ} \mathrm{C}$ 에서 90 분간 증숙추출물 농도에 따른 효과는 각각 $100,133,116,54,42 \%$ 였다, 시료 모두 $2 \mu \mathrm{g} / \mathrm{\mu l}$ 이상의 농도에서부터 세포성장률이 감소하였고, 증숙처리는 비증숙처리에 비해 오히려 세포성장을 억제하였다.

Fig. 2B에서는 건지황 열수추출물과 증숙추출물의 SK-N$\mathrm{SH}$ 세포에 대한 oxidative stress 억제효과를 나타내고 있다. 건지황 열수추출물 농도 $(0,0.5,1,2,4 \mu \mathrm{g} / \mu \mathrm{l})$ 에 따른 효과는 각각 $100,105,128,105,64 \%$ 성장률을 나타내었다. 이와 같은 결과는 $2 \mu \mathrm{g} / \mu \mathrm{l}$ 의 농도에서부터 세포성장률이 감소한 당귀 열수추출물과 같다. 건지황 증숙추출물은 비증숙추출물에 비 해 세포보호 효과가 낮았고, $2 \mu \mathrm{g} / \mu \mathrm{l}$ 이상에서는 강한 독성을

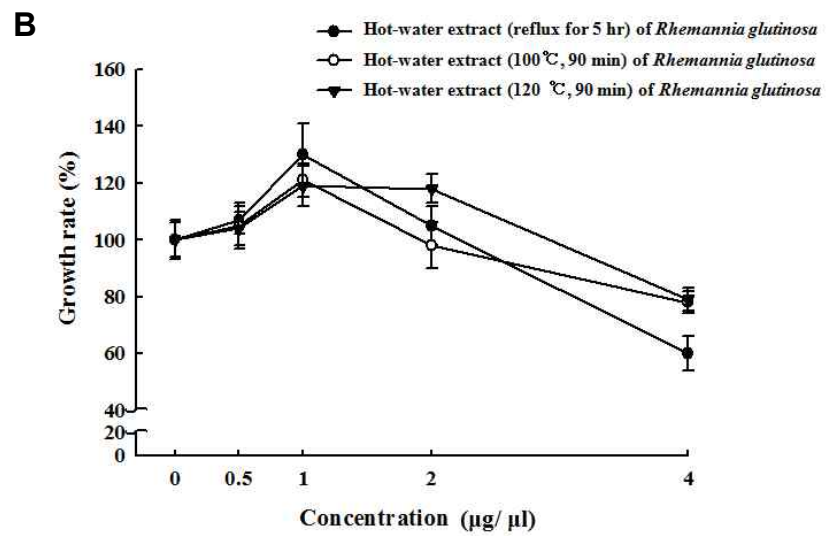

C

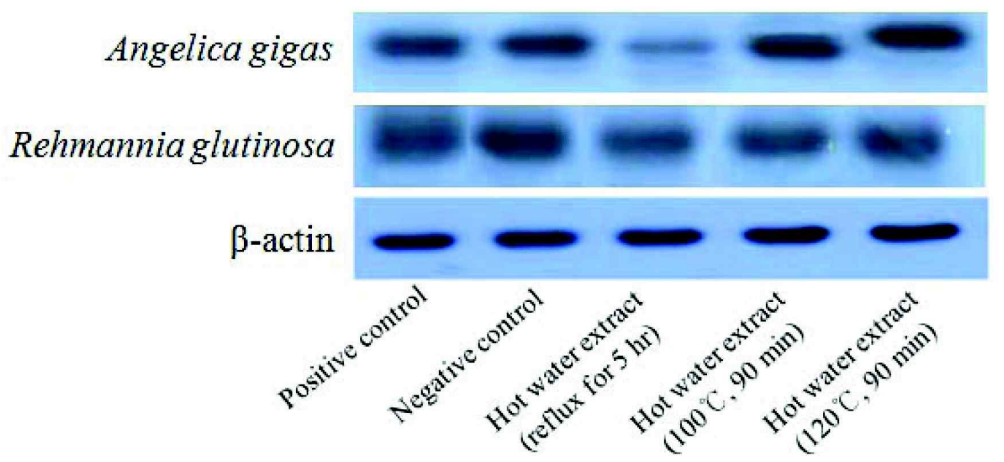

Fig. 2. Effects of hot-water extracts and hot-water extract post heat treatment of Rehmannia glutinosa and Angelica gigas on the proliferation of SK-N-SH cells. Cells were exposured to sample $2 \mathrm{hr}$ prior to $\mathrm{H}_{2} \mathrm{O}_{2}$ treatment. $2 \mathrm{hr}$ later after $\mathrm{H}_{2} \mathrm{O}_{2}$ treatment, cell proliferation and caspase-3 expression was measured by MTT assay (A) and (B), and western blotting (C). 
나타내었다. 이들의 효과는 당귀보다 낮았다. SK-N-SH 세포 보호 효과가 큰 당귀와 건지황의 추출물을 이용하여 apoptosis 신호 전달 물질인 caspase-3 발현 정도를 분석하였다. 이들 추출물 중 열수추출물이 다른 증숙추출물에 비하여 caspase- 3 발현을 억제하였고, 이 효과는 당귀에서 다소 강하였다(Fig. 2C).

\section{열수추출물의 apoptosis 억제효과}

Oxidative stress로부터 세포 보호효과가 가장 우수한 당귀 열수추출물로 $\mathrm{H}_{2} \mathrm{O}_{2}$ 처리에 의한 SK-N-SH의 apoptosis 유발 효과를 PI 염색액으로 핵을 염색한 후 flow cytomer로 분석하 였다(Fig. 3). Fig. 3A와 Table 2에서는 세포에 시료 $1 \mu \mathrm{gg} / \mu \mathrm{l}$ 를
2시간 처리하고 $\mathrm{H}_{2} \mathrm{O}_{2}$ 를 시간별 $(0,1,2$ 시간 $)$ 로 처리한 후의 cell cycle의 각 phase에 함유된 DNA 함량을 나타내고 있다. Apopotic cell (sub-G1 cell)은 control 처리에서는 14.5\% 였고, 처리 1 시간 및 2 시간 후에는 각각 19.4, 5.6\%로 시간이 경과함 에 따라 다소 증가했다가 감소하였다. 또한 처리 2 시간 후의 DNA 함량은 $\mathrm{M}$ phase가 $21 \%$ 로 control이나 1 시간 후의 DNA 함량보다 높았다.

Fig. 3B와 Table 3에서는 시료를 농도 별 $(0,0.5,1,2,4 \mu \mathrm{g} / \mu$ 1)로 2 시간 처리하고 난 후 $\mathrm{H}_{2} \mathrm{O}_{2}$ 를 2 시간 처리 후의 cell cycle 의 각 phase에 함유된 DNA 함량을 나타내고 있다. Apopotic cell (sub-G1 cell)은 control 처리에서는 $14.5 \%$ 였고, $0.5,1$, 2. $4 \mu \mathrm{g} / \mu \mathrm{l}$ 처리에서 각각 $8.5,6.4,20.6,25 \%$ 로 $1 \mu \mathrm{g} / \mu \mathrm{l}$ 처리
A

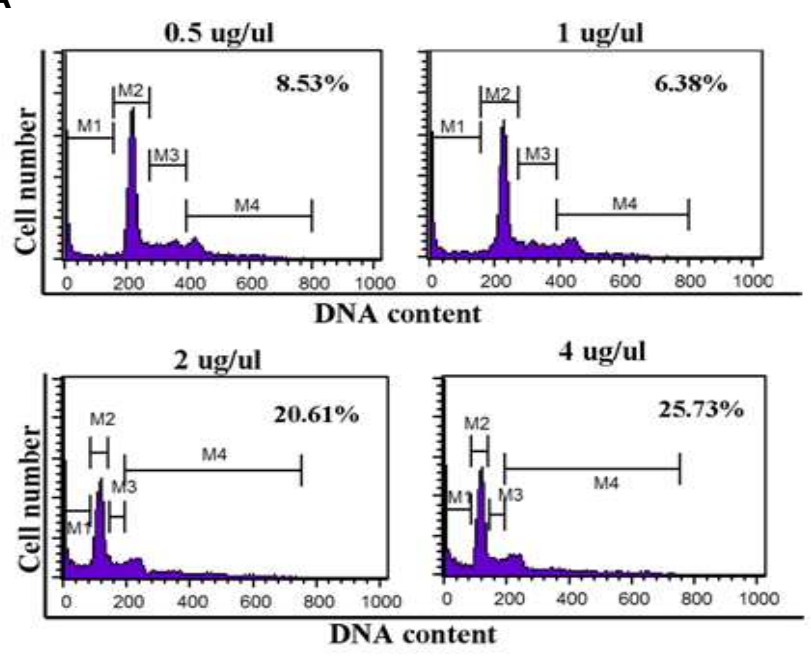

B

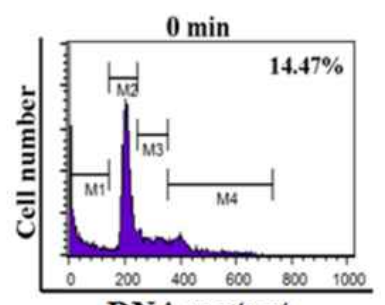

DNA content

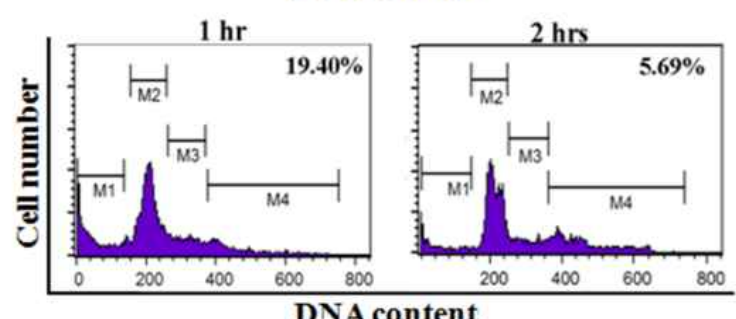

Fig. 3. Distribution of DNA to cell phases. Cells were treated with hot-water extract of Angelica gigas for $2 \mathrm{hr}$ prior to $2 \mathrm{hr}^{\mathrm{H}_{2} \mathrm{O}_{2}}$ treatment.

Table 2. DNA distributions to cell cycles phase of SK-N-SH cells treated with a hot-water extract of Angelicagigas ${ }^{1)}$

\begin{tabular}{lcccccccccc}
\hline Concentration $(\mathrm{ug} / \mathrm{ul})$ & \multicolumn{2}{c}{0} & \multicolumn{2}{c}{0.5} & \multicolumn{2}{c}{1} & \multicolumn{2}{c}{2} & \multicolumn{3}{c}{4} \\
\hline Cell phase & Total cells & $\%$ & Total cells & $\%$ & Total cells & $\%$ & Total cells & $\%$ & Total cells & $\%$ \\
\hline M1 (Sub-G1) & 1405 & 14.5 & 829 & 8.5 & 622 & 6.4 & 1995 & 20.6 & 2475 & 25.7 \\
M2 (S) & 4845 & 49.9 & 5397 & 55.6 & 5497 & 56.4 & 4983 & 51.5 & 4648 & 48.3 \\
M3 (G2) & 1467 & 15.1 & 1649 & 17 & 1849 & 19.0 & 1549 & 16.0 & 1367 & 14.2 \\
M4 (M) & 1171 & 12.1 & 1842 & 18.9 & 1777 & 18.2 & 1151 & 11.9 & 1130 & 11.8 \\
\hline
\end{tabular}

${ }^{1)}$ Data was derived from Fig. 3(A).

Table 3. DNA distributions to the phase of cell cycles (\%) of SK-N-SH cells treated with a hot-water extract of Angelica gigas

\begin{tabular}{lcccccc}
\hline Exposure time $(\mathrm{hr})$ & \multicolumn{2}{c}{0} & \multicolumn{2}{c}{1} & \multicolumn{2}{c}{2} \\
\hline Cell phase & Total cells & $\%$ & Total cells & $\%$ & Total cells & $\%$ \\
\hline M1 (Sub-G1) & 1405 & 14.47 & 1855 & 19.40 & 521 & 5.69 \\
M2 (S) & 4845 & 49.88 & 4816 & 50.37 & 4264 & 46.53 \\
M3 (G2) & 1467 & 15.10 & 1491 & 15.59 & 1123 & 12.26 \\
M4 (M) & 1171 & 12.06 & 941 & 9.84 & 1958 & 21.37 \\
\hline
\end{tabular}

${ }^{1)}$ Data was derived from Fig. 3(B). 


\section{A}

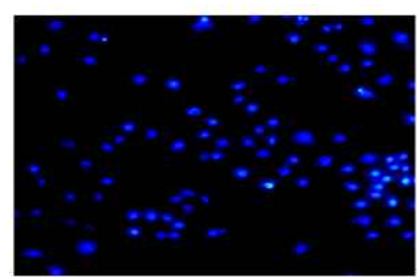

Control

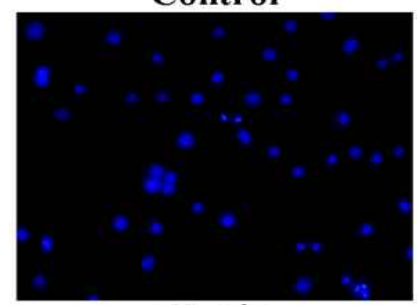

$60 \mathrm{~min}$

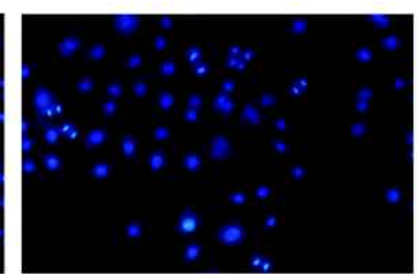

$30 \mathrm{~min}$

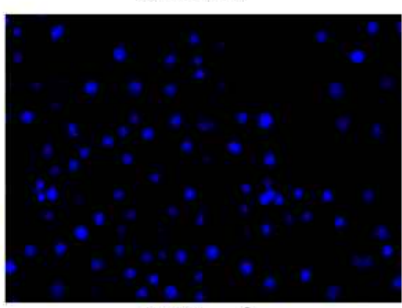

$120 \mathrm{~min}$

B

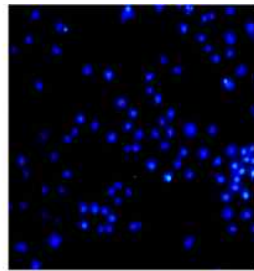

Control

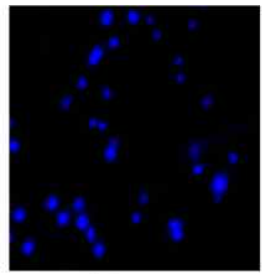

$0.5 \mu \mathrm{g} / \mu \mathrm{l}$

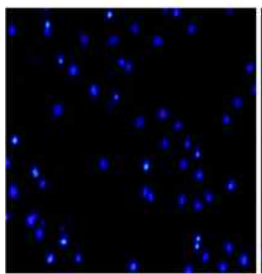

$1 \mu \mathrm{g} / \mu \mathrm{I}$

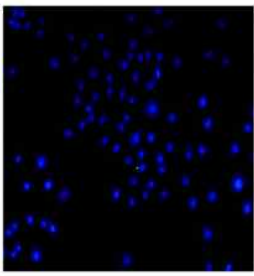

$2 \mu \mathrm{g} / \mathrm{\mu l}$

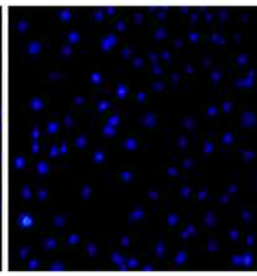

$4 \mu \mathrm{g} / \mu \mathrm{I}$

Fig. 4. Hoechst33258 stainining of cells. Cells were treated with $1 \mu \mathrm{g} / \mu \mathrm{l}$ concentration (A) and treated with various concentrations ( $\mu \mathrm{g} / \mu \mathrm{l})$ (B) of hot-water extract of Angelica gigas for $2 \mathrm{hr}$ prior to $2 \mathrm{hr} \mathrm{H}_{2} \mathrm{O}_{2}$ treatment.

농도에서 가장 적은 apoptotic cell이 존재하였다. $2 \mu \mathrm{g} / \mu \mathrm{l}$ 이상 의 높은 농도에서는 apoptotic cell의 분포가 많았다.

세포의 형태학적 변화를 Hoechst33258로 염색하여 형광현 미경으로 관찰하였다(Fig. 4). Fig. $4 \mathrm{~A}$ 에서는 당귀 열수추출물 을 $1 \mathrm{\mu g} / \mathrm{\mu l}$ 농도로 2 시간 처리하고 $\mathrm{H}_{2} \mathrm{O}_{2}$ 처리시간에 따른 형태학적 변화를 조사하였다. 시료가 처리되지 않은 배지에서 생육한 SK-N-SH 신경모세포가 시료가 처리된 배지에서 생육 한 세포에 비하여 응축되거나 쪼개진 apoptotic body를 관찰 할 수 있었다.

Fig. 4B에서는 당귀 열수추출물 농도별( $(0,0.5,1,2,4 \mu \mathrm{g} / \mathrm{\mu l})$
로 2 시간 처리하고 $\mathrm{H}_{2} \mathrm{O}_{2}$ 를 2 시간 처리에 따른 형태학적 변화 를 조사하였다. 당귀 열수추출물이 처리되지 않은 SK-N-SH 세포가 열수추출물이 처리된 세포에 비하여 응축된 apoptotic body가 더 많았다. 그리고 시료 처리 농도에 따라서도 고농도 $(2 \mathrm{\mu g} / \mu \mathrm{l}$ 이상)로 처리한 경우 apoptotic body가 많이 생겨, 0.5-1 $\mathrm{\mu g} / \mathrm{\mu l}$ 처리가 효과적임을 나타내고 있다.

\section{열수추출물의 항산화 효과}

당귀 열수추출물과 건지황 열수추출물의 항산화능을 $\mathrm{DPPH}$ 법으로 측정하였다(Fig. 5). 당귀 열수추출물, 당귀 증숙

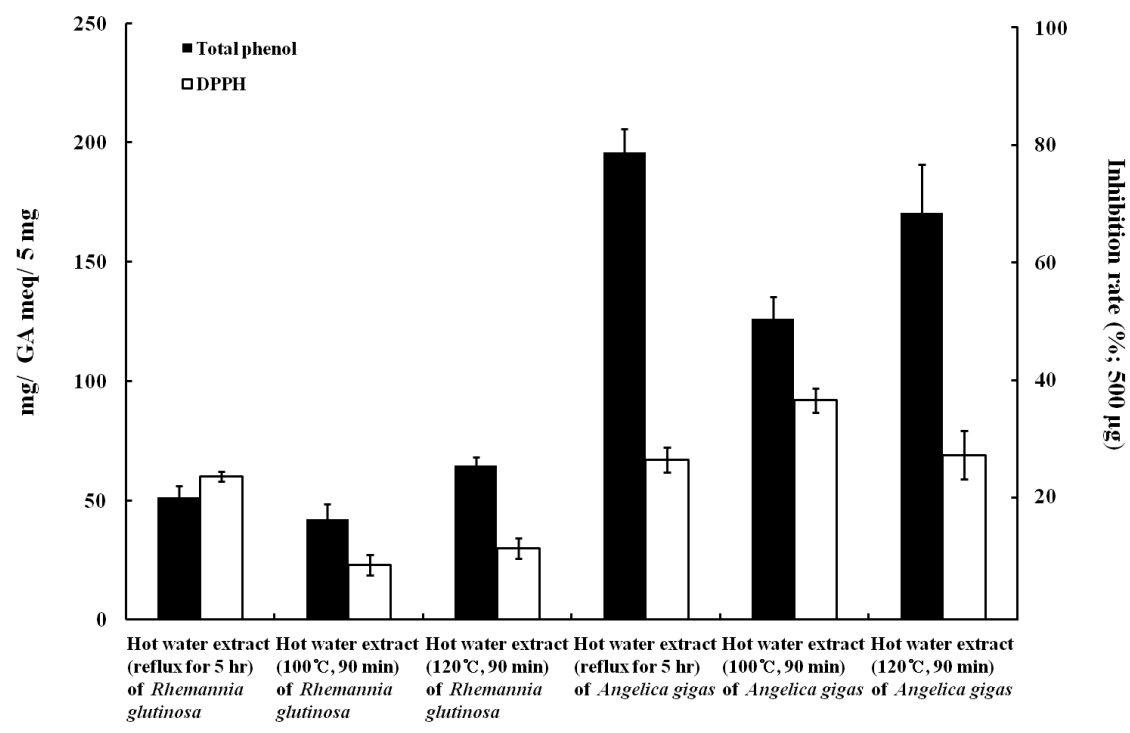

Fig. 5. DPPH free radical scavenging capability and total phenol content of hot-water extract of Rehmannia glutinosa and Angelica gigas. 
추출물, 건지황 열수추출물, 건지황 증숙추출물을 각각 0.5 $\mathrm{mg} / \mathrm{ml}, 0.25 \mathrm{mg} / \mathrm{ml}$ 두 농도로 처리하였다. DPPH 라디칼 소거능은 당귀 추출물이 건지황 추출물보다 좋았으며 당귀 열수추출물의 DPPH 라디칼 소거율이 약 $40 \%$ 로 가장 우수하 였다.

또한, 이들 추출물에 함유된 총 페놀성 화합물을 FolinDenis법[6]으로 측정하여 표준물질(gallic acid)로 환산하였다. 추출물 $5 \mathrm{mg}$ 에 함유된 페놀 함량은 당귀 열수추출물이 약 196 $\mu \mathrm{g}$ 으로 가장 높았고, 증숙추출물에 각각 $126 \mu \mathrm{g}, 170 \mathrm{ug}$ 함유 되어 있었다. 건지황 추출물에는 당귀 추출물보다 낮은 함량 이 함유되어 있었다.

\section{고 찰}

인체신경모세포 SK-N-SH 의 증식 촉진을 위한 한약재(당 귀, 건지황, 작약 및 천궁)의 추출방법을 연구한 결과 열수추출 법(환류냉각, 5 시간)에 의한 추출물이 증숙추출물보다 oxidative stress를 받은 SK-N-SH 세포의 증식을 낮은 농도 $(1 \mu \mathrm{g} / \mu \mathrm{l}$ 이하)에서는 촉진시켰지만, 이보다 높은 농도에서는 억제시켰 다. 또한 에탄올추출물은 전 처리농도에서 SK-N-SH 세포의 증식을 억제하였다. SK-N-SH에 대한 증식촉진 효과가 가장 큰 당귀 열수추물은 caspase-3의 발현 및 apoptosis를 억제하 였다.

치료나 예방을 목적으로 한약재에 함유된 물질을 추출하는 방법은 주로 열수추출법[3,4], 고온고압추출법[13]이나 용매추 출법[27,32]이 활용되고 있다. 이들 방법은 사용 목적에 따라 그 추출방법이 상이할 수 있다. 예를 들면, 암치료용으로 사용 할 경우 한약재에 함유된 거의 모든 물질을 추출할 필요가 있어 고온 및 고압 추출방법이 우수한 방법이다[14]. 그러나 SK-N-SH 세포의 경우는 정상세포이고, 이 세포의 생육을 촉 진하거나, 사멸을 억제함으로써 사람의 기억력을 증진시키고 기억력 퇴화를 방지하여, 알쯔하이머 병을 치료하거나 예방할 수 있다. 따라서 이 경우는 암세포의 사멸과는 달리 한약재의 추출방법이 달라야 할 것이다. 본 연구에서도 증숙추출물과 에탄올추출물은 SK-N-SH의 증식을 억제하였다. 따라서 이들 방법은 적당하지 않고, 단순히 열수추출방법이 가장 우수하였 다. 이와 같은 방법은 아직 연구된 바가 없지만, Park [25] 등의 열수추출물이 심근세포 $\mathrm{H} 9 \mathrm{c} 2$ 의 증식을 촉진하고, 세포사멸을 억제하는 결과와 유사하다.

열수추출물이 다른 방법으로 추출한 추출물보다 SK-N-SH 증식 또는 보호 능력이 우수한 것은 아마도 약재 추출물에 포함된 페놀성 화합물에 기인 하는 것으로 추정된다. 당귀 열 수추출물에서 총 페놀성 화합물이 다른 추출물보다 많았고, 또한 항산화능(DPPH 라디칼 소거능)도 우수하였다(Fig. 5). 이와 같은 결과는 에탄올추출물에 비하여 열수추출물에서 페 놀성 화합물의 함량이 높고 황산화 활성에 기여한다는 보고와
일치한다[24].

한약재 중 당귀 열수추출물이 가장 우수한 SK-N-SH 세포 증식촉진 및 사멸억제 효과가 우수하였다(Fig. 2(A), Table 2). 당귀에는 coumarine계의 decursin, decursinol angelate와 $\beta$ -sitosterol 등의 성분이 함유되어있고[8,11], 이러한 당귀는 면 역효과[7], 항산화효과[3,4], 항돌연변이효과[26], 항염증효과 [29], 항암효과[18,19] 등의 효과가 있다고 보고되었다. Nam과 Kang [23]은 130여 종의 식물성 한약재 열수추출물의 항산화 활성 검증 결과 25 종이 대조군에 비해 $80 \%$ 이상의 전자공여 능을 나타내었는데 이는 페놀성 화합물 및 플라보노이드류가 항산화 활성을 나타내는 주요물질이라고 보고하였다 $[10,22]$. 또한 당귀 추출물은 세포사멸 감소 효과가 있음이 밝혀졌다 [16]. 따라서, 본 연구에서 SK-N-SH 세포 증식촉진 및 사멸억 제 효과는 열수추출법이 당귀에 함유된 페놀성 화합물과 이 들 물질을 효율적으로 가장 많이 추출할 수 있는 방법이라고 추정된다.

결론적으로 한약재의 SK-N-SH 세포 증식촉진 및 사멸억제 를 위한 추출방법 중 열수추출방법이 가장 우수하였으며, 여 러 한약재 중에서는 당귀가 SK-N-SH 세포 증식촉진 및 사멸 억제 효과가 가장 우수하였고, 건지황도 우수하였다. 따라서 이들 한약재를 사람의 인지능력 향상 및 관련 세포사멸 억제 를 위한 소재로 활용할 수 있을 것이다.

\section{References}

1. Ahn, K. S. 1996. A study on the anticancer and immunostimulating agents from the root of Angelica gigas Nakai. Ph.D Disseration, Korea University, Seoul, Korea.

2. Blois, M. S. 2003. Antioxidant determinations by the use of a stable free radical. Nature 181, 1199-1200.

3. Cho, Y. H., B. C. Lee, J. H. Kim, J. H. Kim, H. B. Pyo, Y. H. Zhang, and H. D. Park. 2005. Effect of Artemisia anomala S. Moore on antioxidant activity and melanogenesis. Korean J. Pharmacogn. 36, 273-277.

4. Choi, S. Y., S. H. Kim, J. S. Kim, T. Y. Ha, S. R. Kim, K. S. Kang, and I. K. Hwang. 2005. Evaluation of the estrogenic and antioxidant activity of some edible and medicinal plants. Korean J. Food Sci. Technol. 37, 549-556.

5. Deliza, R., A. Rosenthal, F.B.D. Abadio, C.H.O. Silva, and C. Castillo. 2005. Application of high pressure technology in the fruit juice processing: Benefits perceived by consumers. J. Food Eng. 67, 241-246.

6. Folin, O. and W. Denis. 1912. On phosphotungstic-phosphomolybdic compounds as color reagents. J. Biol. Chem 12, 239-249.

7. Han, S. B., Y. H. Kim, C. W. Lee, S. M. Park, H. Y. Lee, Y. H. Ahn, I. H. Kim, and H. W. Kim. 1998. Characteristic immunostimulation by angelan isolated from Angelica gigas Nakai. Immunopharmacology 40, 39-48.

8. Hwang, J. B. and M. O. Yang. 2002. Comparison of chemical 
components of Angelica gigas Nakai and Angelica acuriloba kitagawa. Korea J. Food Sci. Technol. 29, 1113-1118.

9. Islam, M. A., Y. S. Kim, W. J. Jang, S. M. Lee, H. G. Kim, S. Y. Kim, J. O. Kim, and Y. L. Ha. 2008. A mixture of trans, trans conjugated linoleic acid induces apoptosis in MCF-7 human breast cancer cells with reciprocal expression of bax and bcl-2. J. Agric, Food Chem 56, 5970-5976.

10. Kang, Y. H., Y. K. Park, S. R. Oh, and K. D. Moon. 1995. Studies on the physiological functionality of pine needle and mugwort extracts. Korean J. Food Sci. Technol. 27, 978-984.

11. Kim, E. Y. I. H. Baik, J. H. Kim, and S. R. Kim. 2009. Isolation and purification of decursin and decurisinol angelate in Angelica gigas Nakai. J. Korean Soc. Food Sci. Nutr. 38, 653-656.

12. Kim, D. H., W. Y. Jung, S. J. Park, J. M. Kim, S. Lee, Y. C. Kim, and J. H. Ryu. 2010. Anti-amnesic effect of ESP-102 on Aß1-42-induced memory impairment in mice. Pharmacol. Biochem Behav. 97, 239-248.

13. Kim, M. R., I. H. Kim, and J. H. Shim. 2005. The analysis of volatile components of fresh ginseng, red ginseng and white ginseng by solvent free solid injector (SFSI) techniques. Korean J. Environ. Agric. 24, 164-168.

14. Kim, Y. C., H. D. Hong, J. H. Rho, C. W. Cho, Y. K. Rhee, and J. H. Yim. 2007. Changes of phenolic acid contents and radical scavenging activities of ginseng according to steaming times. Korean J. Ginseng Res. 31, 230-236.

15. Kim, Y. S., R. M. Cerbo, C. K. Hah, K. N. Bahn, J. O. Kim, and Y. L. Ha. 2008. Growth inhibition of osteosarcoma cell MG-63 by a mixture of trans, trans conjugated linoleic aicd isomers: possible mechanistic actions. J. Food Sci. 73, T7-15.

16. Koo, U., H. J. Lee, D. H. Lee, H. J. Lee, A. R. Ham, E. Y. Cho, and W. Mar. 2008. Anti-oxidative effect of some plant extracts against nitric oxide-induced oxidative stress on neuronal cell. Korean J. Pharmacogn. 39, 290-294.

17. Korea Institute for Health and Social Affairs, http://www.kihasa.re.kr.

18. Lee, S. H., Y. S. Lee, S. H. Jung, K. H. Shin, B. K. Kim, and S. S. Kang. 2003. Anti-tumor activities of decursinol angelate and decursin from Angelica gigas. Arch Pharm Res. 26, 727-730.

19. Li, L., W. Li, S. W. Jung, Y. W. Lee, and Y. H. Kim. 2011. Protective effects of decursin and decursinol angelate against amyloid $\beta$-protein-induced oxidative stress in the PC12 cell line: The role of Nrf2 and antioxidant enzymes. Biosci. Biotechnol. Biochem 75, 434-442.

20. Locatelli, M., F. Travaglia, J. D. Coisson, A. Martelli, C. Stevigny, and M. Arlorio. 2010. Total antioxidant activity of hazelnut skin (Nocciola Piemonte PGI): Impact of different roasting conditions. Food Chem 119, 1647-1655.

21. Maritinez, S., L. Valek, J. Piljac, and M. Metikos-Jukovic. 2005. Determination of wine antioxidant capacity by derivative potentiometric titration with electrogenerated cholorine. Eur. Food Res. Technol. 220, 658-661.
22. Moon, J. S., J. S. Park, Y. M. Park, Y. S. Hwang, E. H. Kim, J. W. Park, I. B. Park, S. W. Kim, S. G. Kang, Y. K. Park, and S. T. Jung. 2008. Antioxidant activaties of methanol extracts from prunella uulgaris. J. Korean Soc. Food Sci. Nutr. 37, 1535-1541.

23. Nam, S. H. and M. Y. Kang. 2000. Screening of antioxidative activity of hot-water extracts from medicinal plants. $J$. Korean Soc. Agric. Chem Biotechnol. 43, 141-147.

24. Park, Y. S. 2002. Antioxidative activities and contents of polyphenolic compound of medicinal herb extracts. J. Easat Asian Soc. Dietary Life 12, 23-31.

25. Park, C., H. S. So, S. H. Shin, J. Y. Choi, I. Lee, J. K. Kim, S. Y. Chung, and R. Park. 2007. The water extract of Omija protects $\mathrm{H} 9 \mathrm{c} 2$ cardiomyoblast cells from hydrogen peroxide. Phytother. Res. 21, 81-88.

26. Salikhova, R. A. and G. G. Poroshenko. 1995. Antimutagenic properties of Angelica archangelica L. Vestn. Ross. Akad Med Nauk 1, 58-61.

27. Santos-Buelga, C., G. Williamson, and M. Saltmarsh. 2003. Methods in polyphenol analysis. pp. 1-16, Royal Society of Chemistry, Cambridge, England.

28. Seo, H. Y., J. H. Kim, H. P. Song, D. H. Kim, M. W. Byun, J. H. Kwon, and K. S. Kim. 2007. Effects of gamma irradiation on the yields of volatile extracts of Angelica gigas Nakai. Int. J. Radiat. Phys. Chem 76, 1869-1874.

29. Shin, S., J. H. Jeon, D. Park, J. Y. Jang, S. S. Joo, B. Y. Hwang, S. Y. Choe, and Y. B. Kim. 2009. Anti-inflammatory effects of an ethanol extract of Angelica gigas in a carrageenan-air pouch inflammation model carrageenan-air pouch inflammation model. Exp. Anim 58, 431-436.

30. So, Y. K., Y. L. Ki, H. S. Sang, and C. K. Young. 2005. Four new neuroprotective dihydropyranocoumarins from Angelica gigas. J. Nat. Prod 68, 56-59.

31. Sohn, E. S., S. W. Kim, Kang, and S. P. Lee. 2004. Domestic R\&D trend analysis of functional food using medical plants. Applied Chem 8, 470-473.

32. Turkmen, N., F. Sari, and Y. Sedat Velioglu. 2006. Effect of extraction solvents on concentration and antioxidant activity of black and black mate tea polyphenols determined by ferrous tartrate and Folin-Ciocalteu methods. Food Chem 99, 835-841.

33. Yu, H. H., S. J. Seo, Y. H. Kim, H. Y.Lee, R. K. Park, H. S. So, S. 1. Jang, and Y. O. You. 2006. Protective effect of Rehmannia glutinosa on the cisplatin-induced damage of HEI-OCI auditory cells through scavenging free radicals. $J$. Ethnopharmacol. 107, 383-388.

34. Rakib, Md. A., Y. S. Kim, W. J. Jang, B. D. Choi, J. O. Kim, I. K. Kong, and Y. L. Ha. 2010. Attenuation of 12-O-tetradecanoylphorbol-13-acetate (TPA)-induced gap junctional intercellular communication (GJIC) inhibition in MCF-10A cells by c9,t11-conjugated linoleic acid. J. Agric. Food Chem $58,12022-12030$. 
초록 : 추출방법에 따른 한약재의 인체신경모세포 SK-N-SH 보호 효과

권정민 ${ }^{1,2} \cdot$ 문연규 ${ }^{1,2} \cdot$ 김영숙 ${ }^{2} \cdot$ 정지영,2,3 $\cdot$ 하영래 ${ }^{1,2} \cdot$ 양재경 ${ }^{2,3 *}$

( ${ }^{1}$ 경상대학교 응용생명과학부, ${ }^{2}$ 경상대학교 농업생명과학연구원, ${ }^{3}$ 경상대학교 환경산림과학부 환경임산공 학전공)

한약재의 추출방법에 따른 인체신경모세포 SK-N-SH에 대한 보호 효과를 연구하였다. 당귀, 건지황, 작약 및 천궁을 시료로 사용하였고, 열수추출(환류냉각, 5 시간), 증숙추출 $\left(100^{\circ} \mathrm{C}\right.$ 및 $120^{\circ} \mathrm{C}, 90$ 분 후 열수추출) 방법과 에탄 올추출(환류냉각, 5 시간)방법을 비교하였다. 추출물을 농도별로 SK-N-SH 세포에 2 시간 처리한 후 $\mathrm{H}_{2} \mathrm{O}_{2}$ 로 250 $\mu \mathrm{M}$ 로 2 시간 산화스트레스를 유발한 다음 세포독성 및 apoptosis와 caspase-3의 발현 정도를 측정하였다. 모든 약재의 열수추출물이 다른 추출물보다 세포 증식을 촉진하였고, apoptosis를 억제하였다. 한약재 열수추출물 1 $\mu \mathrm{g} / \mathrm{\mu l}$ 농도까지는 세포증식을 촉진하였지만, 그 이상의 농도에서는 오히려 감소시켰다. 열수추출물은 다른 추출 물보다 총페놀성 화합물이 많이 함유되어 있었고, 항산화능이 높았다. 또한, 이와 같은 효과는 당귀의 열수추출물 이 다른 약재 열수추출물보다 우수하였다. 본 연구결과는 약재의 열수추출법이 인체신경모세포인 SK-N-SH의 증 식과 세포사멸 억제를 위해 가장 우수한 방법이었고, 당귀 열수추출물이 가장 우수한 효과를 지니고 있어 기억력 보호나 상실억제제로 활용할 수 있을 것이다. 